\title{
ON SOME EIGHTEENTH CENTURY ANIMAL PORTRAITS OF INTEREST FOR SYSTEMATIC ZOOLOGY
}

by

\author{
P. TUIJN ${ }^{1)}$ \& P. J. VAN DER FEEN ${ }^{2}$ )
}

The English zoologist Thomas Pennant (1726-1798) visited The Hague in 1765 . There he met another zoologist, Dr. Peter Simon Pallas (1741-1811). On July 30th they visited together the Dutch painter Aart Schouman (1710-1792). Pennant's diary records: “Accompanied Doctor Pallas a very ingenious young man from Berlin, to Mr. Schouman's, an exellent painter of beasts and birds in oil and water colours. Took a list of several which I want.-Great Owl. Sort of Nightingale. Young Cuckoo. Ruffe and Reeve. Kol eend a Duck, male and female. Teal. Hook Bill Duck. Een Zee coot. My new Guillemot. Wild Goose. Brent Goose Bernacle. Three small Divers. Ermine. Tragulus. Little Goat. Grey Squirrel. Two black Monkeys. Paca. Mungos Civet Cat. Little Antelope at the Menagery. Boar at ditto." From Pennant's autobiography (1793) we know that the idea of a Synopsis of Quadrupeds was then in his mind. The first edition of this book appeared at Chester, 1771, with 31 plates. We could, however, not trace any work by Schouman in it, nor in the second edition which appeared in London 1781, entitled: "History of Quadrupeds", now with 52 plates.

In 1766 and following years A. Vosmaer edited descriptions of animals kept in the Menagery of Prince William V of Orange-Nassau near The Hague. These descriptions were illustrated with plates engraved mostly by Simon Fokke after watercolours by Schouman and others. In some copies of these descriptions the plates are hand-coloured. Pennant's new edition of the History of Quadrupeds, London 1793, contains several engravings, signed: P. Mazell Sculp (sit), which are easily recognizable as reversed copies of Fokke's engravings after Schouman.

Vosmaer did not use the binominal nomenclature consistently and the few Latin names used in his

1) Dorpsstraat 9, Renswoude (Netherlands).

2) Domburgseweg 6, Domburg (Netherlands). publications are, therefore, not available according to the Rules of Zoological Nomenclature. Pallas and Schreber, however, have based several diagnoses on descriptions and plates published by Vosmaer. In these cases the specimens, alive or dead, described by Vosmaer and depicted by Schouman and other artists are the holotypes of the species named by Pallas and Schreber. Where the stuffed specimens are now is not sure. Probably, in 1795 with the rest of Prince William's cabinet, they were sent to Paris, and possibly brought back again by Brugmans in 1815 (cf. Engel, 1939 , p. 300-302).

In this light it seems all the more interesting to know where and how the "portraits" by Schouman and his fellow artists have been used. Mr. L. J. Bol, former Director of the musea at Dordrecht and an authority on Schouman and his contemporaries, was so kind as to give us recently his opinion on the authenticity of the original drawings in the possession of the Artis-Bibliotheek, Universiteit van Amsterdam (indicated hereafter as $\mathrm{A}$.)

For the present we will confine ourselves to the mammals and in the following list we will maintain the chronological order in which the parts of Vosmaer's book were published.

In the different copies of the Dutch edition of this work known to us, the plates are similar in essentials. In some of them however, more plates bear the name of the animal depicted than in others. We will follow the "Artis-Bibliotheek" copy and for the plates without names will state those used by Vosmaer in his text. Also, there exists a French edition of the Regnum Animale likewise published in different parts from 1767 until 1805. A copy of this edition, which was kindly lent to us by the Rijksmuseum van $\mathrm{Na}$ tuurlijke Historie, Leiden, shows some peculiarities. The captions in this volume are in Dutch, no French texts are engraved on the plates which, apart from some minor differences (in the numbers engraved on 
some of them for instance and in the reduced size of the Giraffe-skeleton engraving-effected by putting the measure at the left and the letter press between the legs-), are identical with the Dutch copies we know. Further, though having a titlepage dated 1804 (just as in the copies in Dutch), the latest issue on birds (le Courli africain, probably Geronticus calvus (Boddaert, 1783)) is only published in 1805 according to its titlepage. Furthermore, on this titlepage of 1805 is stated that the bird has been "conserve dans le Museum", whereas in the Dutch edition (which has this issue on Geronticus calvus published in 1804) the bird is said to be brought to the menagerie (alive?).

Buffon, too, in his Histoire Naturelle has copied plates of Vosmaer. Usually he did so only after Allamand, who supplemented the Amsterdam edition of his work, had made use of Vosmaer's plates in his additions. As Buffon's work was very famous, we thought it worth while to refer to the Histoire $\mathrm{Na}$ turelle also.

Several authors again copied plates, which were originally published by Vosmaer, from Buffon, for instance Desmarest (1820). It would lead us too far to trace all these authors. And, as their copying artists were not always very capable, the resemblances to Schouman's originals are sometimes not quite convincing.

\section{Phacochoerus aethiopicus}

(Pallas, 1766, Miscellanea Zoologica: 16). (Wart Hog).

Of this animal we know the following illustrations traceable to the menagerie of Prince William, where it was still living at the time of Pallas' and Vosmaer's descriptions.

a A watercolour, signed A:S: (A). Picture and signature authentic according to Bol. Measurements: $165 \times 227$ mm. (Fig. 1).

$b \quad$ An Indian ink painting, signed van Kuijk $f(A)$. Almost the same posture as in A, but with different size and scenery. Measurements: $200 \times 156$ $\mathrm{mm}$. According to Thieme-Becker: Allgemeines Lexikon der bildenden Künstler, has Karel van Cuyck (living from 1724 till after 1776) been working for Vosmaer.

$c \quad$ An Indian ink drawing signed A. Schouman del. (A). Almost identical with $b$, background somewhat more detailed, the big teeth different. According to Bol, signature and drawing are by Schouman. Measurements: $196 \times 153 \mathrm{~mm}$. $d \quad$ In Bol (1960, 36/cat 110) a paradisical scene is reproduced inspired by the menagerie of Prince William. At right, in the foreground, a reversed image (mirror image) of $a, b$, and $c$. (A).

$e \quad$ An engraving in Vosmaer, Regnum Animale (issue of 1766), signed S. Fokke fe, not, as usual, almost "printed" underneath the engraving in the margin, but somewhat concealed near the lower side at right. Seems a reversed copy of $c$, teeth more like $b$, background not exactly as in $c$. Called in the text: Afrikaansch breedsnuitig varken.

$f \quad$ An engraving in Pallas, Miscellanea Zoologica (1766) Tab. II signed: A. Schouman del. S. Fokke sc. Mentioned in the text as: Aper aethiopicus. Very much like $e$, background slightly different, teeth like c. In Pallas, l.c. Tab. IV fig. 1, 2 and 4 some details of this same animal are shown. This engraving is signed: $\mathrm{J}$. J. Bylaert fec.

g An engraving in Pallas, Spicilegia Zoologica (issue of 1767): 3, Tab. I, signed C. B. Glassbach Sc. Berol.. Almost exactly reversed copy of $f$, teeth simplified, background somewhat different. Called in the text: Aper aethiopicus.

Pallas, Spic. Zool. XI (1776): 84, Tab. V (= Additamentum ad fasc. II) mentions the further history of this specimen. The animal, after having seriously wounded a keeper in The Hague, was sent to "Blauw Jan" in Amsterdam (Engel, 1939 : 258) where it died. At the instigation of Schlosser it was depicted for Pallas, who reproaches Vosmaer for not having obliged the zoologists of his day by studying and measuring this dead animal accurately, which was so dangerous when alive.

$h \quad$ "Le Sanglier d'Afrique", an engraving in Buffon, Hist. Nat. XV (1771, Amsterdam) Planche I, signed Schouman, ad viv.del. C. F. Fritzsch, sc. Almost as $e$, scenery different. The same engravings of this Amsterdam edition were used for the Buffonedition in Dutch (Tuijn, 1966, note II nr. 3).

$i$ "Le Sanglier d'Afrique", an engraving in Buffon, Histoire Naturelle Suppl. Tome III (1776) Pl. XI signed: De Sève del., M. R. veuve Tardieu. As is stated in the text (l.c., p. 77) the engraving was copied from the Amsterdam edition.

\section{Sylvicapra grimmia coronata \\ (Gray, 1842, Ann. Mag. Nat. Hist. (I) 10 : 266) (Crowned Duikerbok).}

The following illustrations have been prepared from the specimen that was living for some time in the menagerie. 


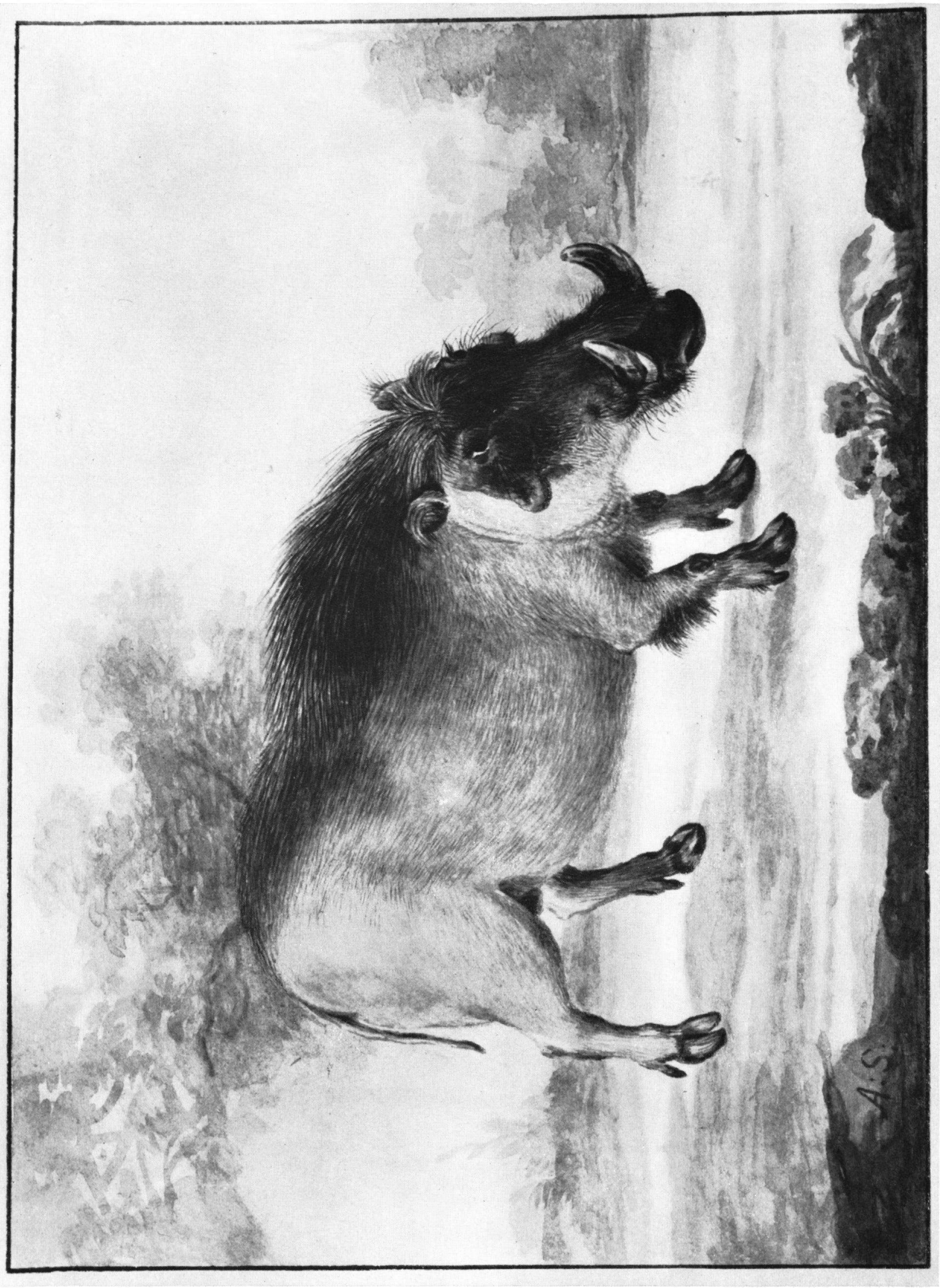

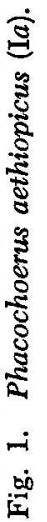



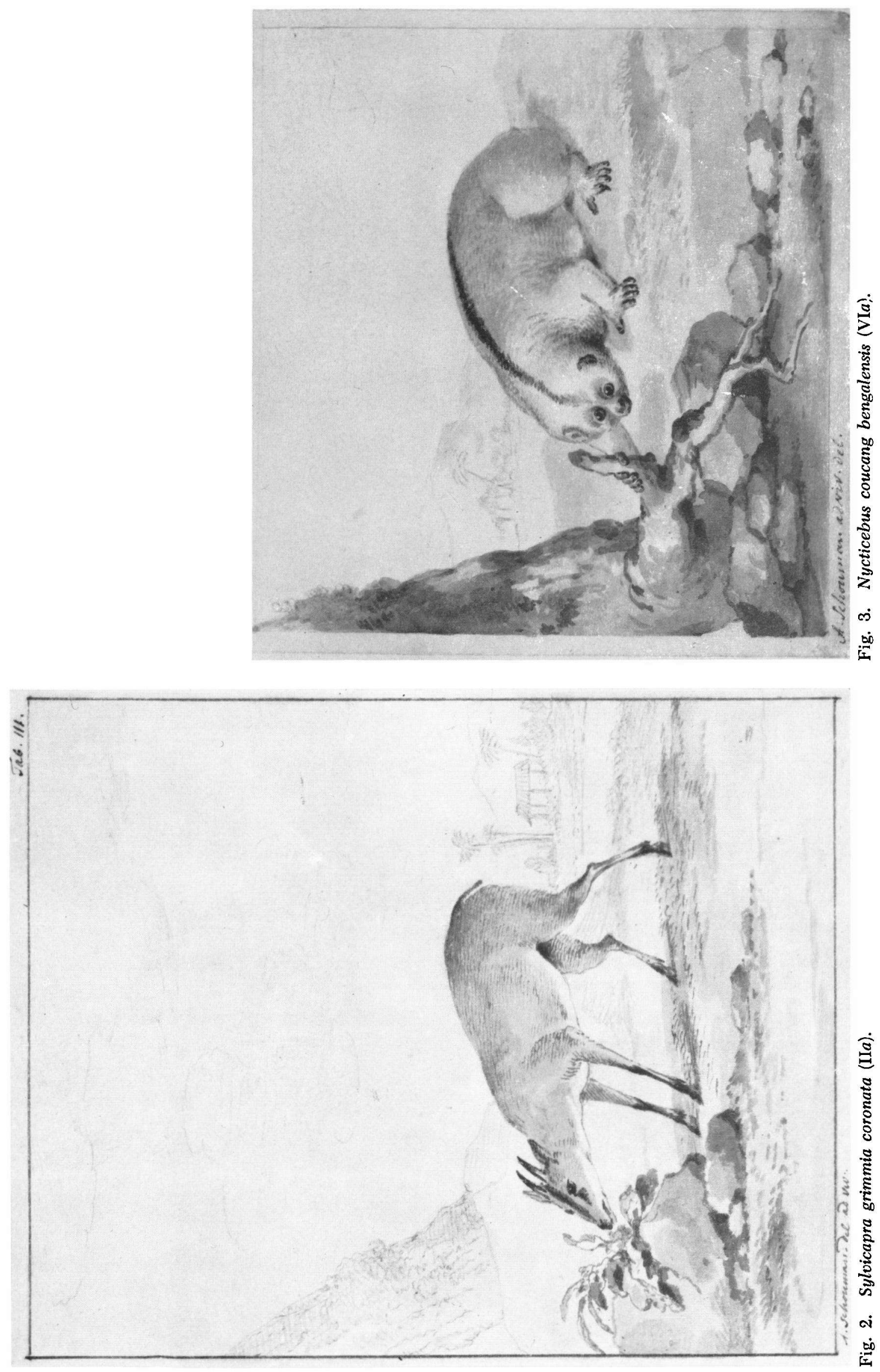

Downloaded from Brill.comఠ4/26/2023 12:13:56PM 

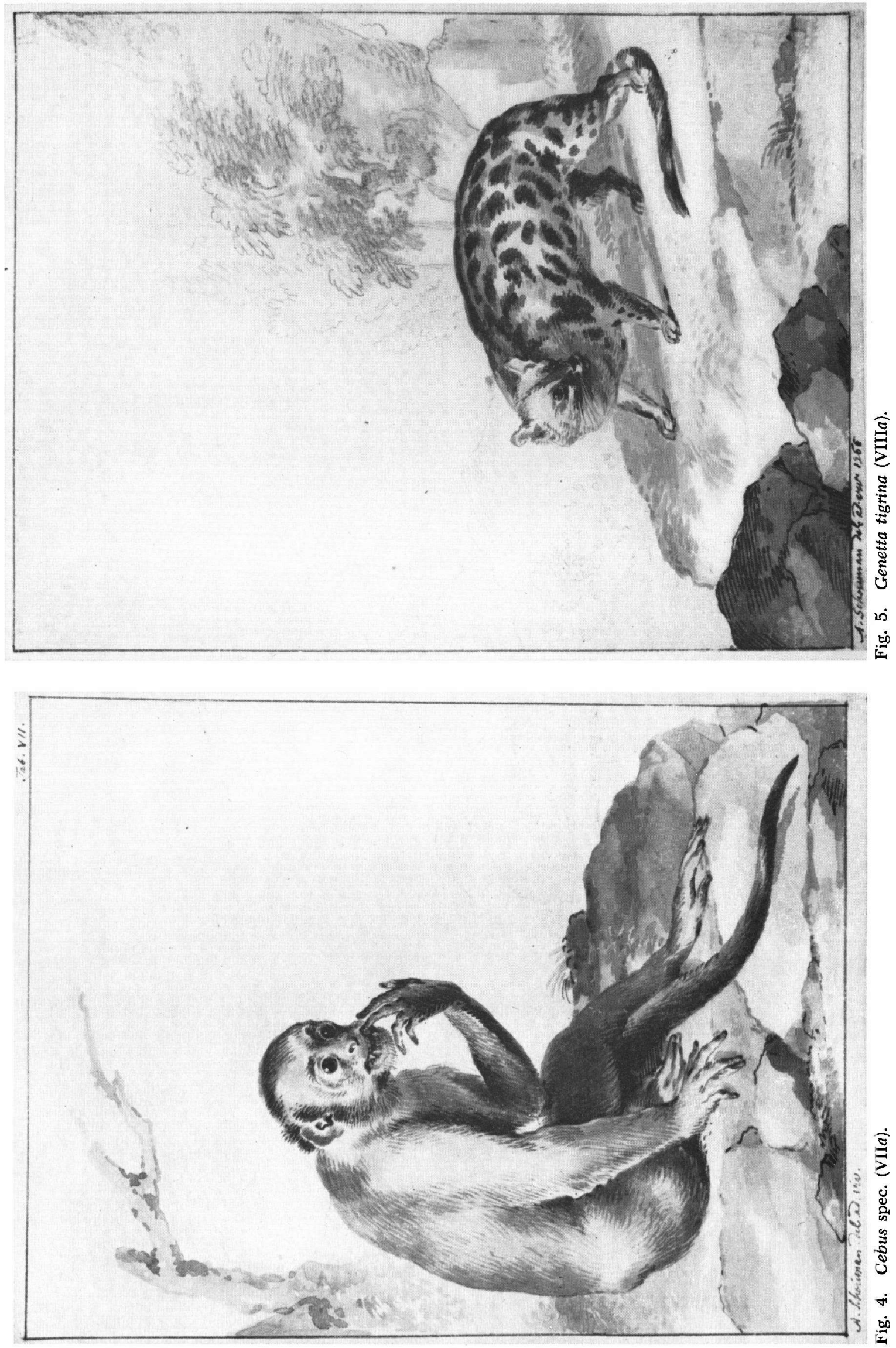

Downloaded from Brill.com04/26/2023 12:13:56PM 

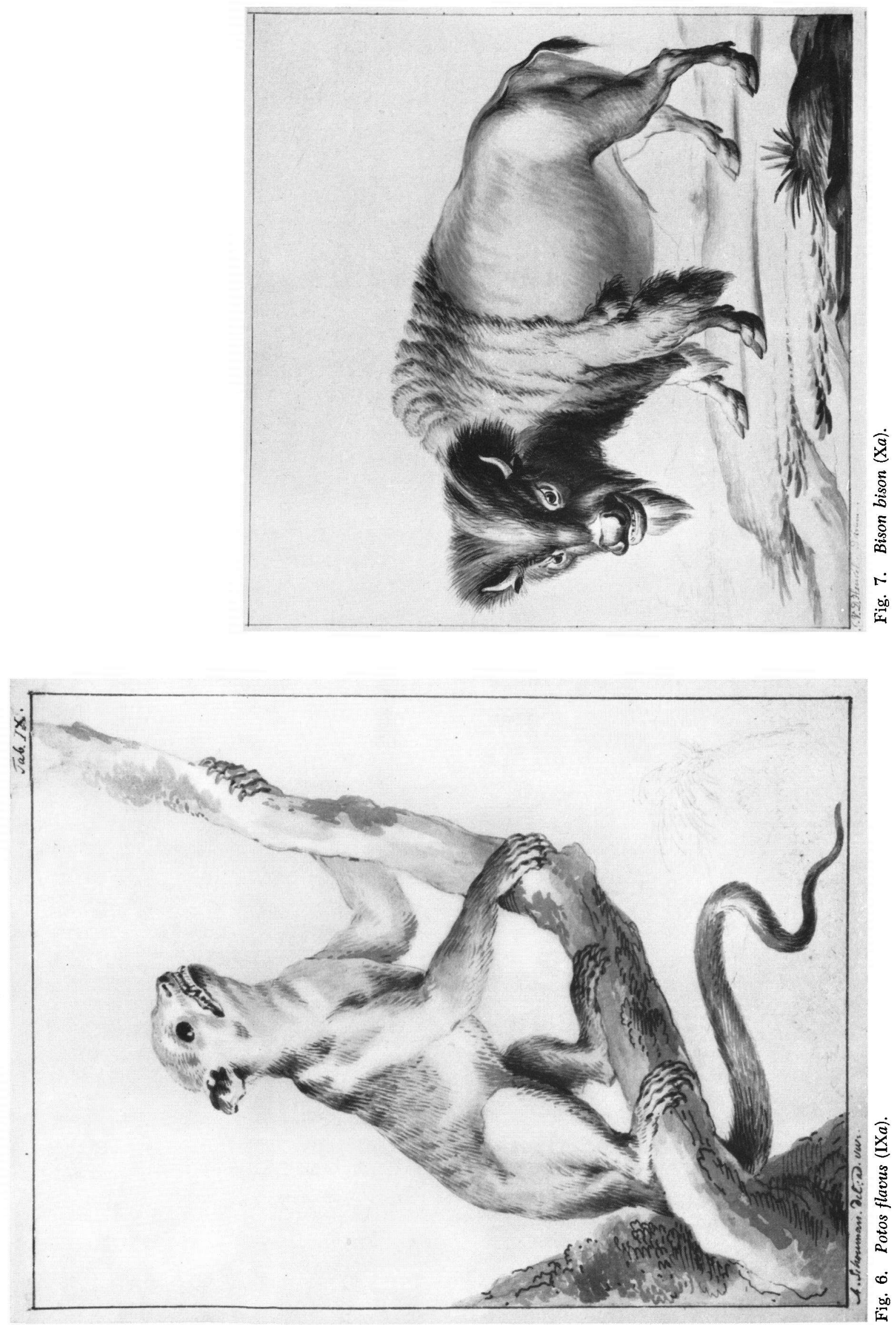

Downloaded from Brill.com04/26/2023 12:13:56PM 
$a \quad$ An Indian ink painting signed: A. Schouman, del.ad viv (A). According to Bol not by Schouman, but possibly a copy by an imitator, as even the engraving $(b)$ seems more artistic. Measurements: $203 \times 159$ mm. (Fig. 2). ${ }^{\text {) }}$

$b \quad$ An engraving in Vosmaer, Regn. Anim. (issue of 1766) signed: A. Schouman ad viv. del. Du Boulois sculp. Reversed copy of $a$. Called in the text: Guineesch Jufferbokje.

c In Pallas, Misc. Zool. (1766) Tab. III, in the background Sylvicapra grimmia coronata is recognizable (cf $a$ and $b$ ).

Depicted differently, but based on the same specimen, as is stated explicitly in the descriptions, are:

$d \quad$ An engraving in Pallas Misc. Zool (1766) Tab. I. signed: J. J. Bijlaert fec. Called in the text: Antilope grimmia. In Pallas, l.c., Tab. IV, fig. 3 a, b, signed: J. J. Bijlaert fec., details of the horns of this animal are pictured.

$e \quad$ "Antilope Grimmia Pall", a coloured engraving in Schreber, die Säughtiere (1785) Tab. 260, signed: I. E. Ihle del. I. F. Volckart sc. A reversed copy of $d$, scenery different. The dates of publishing of Schreber's works are given here according to Sherborn (1891).

$f \quad$ An engraving in Pallas, Spic. Zool. (issue of 1767) Tab. III signed: A. Schouman delin. C. B. Glassbach sculp. Berol. Different. Called in the text: Antilope grimmia.

g "La Grimme", an engraving in Buffon, Hist. Nat. XV (1771, Amsterdam) Planche VI signed: I. S. ad viv.del. C. F. Fritzsch, sc. Similar to $f$. The artist's initials are curious, should be A(art) S.(chouman).

$h \quad$ "La Grimm", an engraving in the first Paris edition of Buffon, Hist. Nat. Suppl. Tome III (1776) Planche XIV. Though looking quite different, it is explicitly stated on page 98 that this engraving is

1) When this article was in the press Mr. M. D. Haga kindly called our attention to a watercolour by Schouman in the collection of Rijksprentenkabinet, Amsterdam (Inv.nr. 60: 106). It could well be the original after which $a$ was painted. In verso is written: "een bruin bokje levensgroot als een ordinaare Eyslandtse hondt geteekent op ' $t$ Loo 1765 na 't leven", and: "Guineesche Juffer bokje levensgroot als een Klijn reebokje. na het leven getekt in de diergaarde van Zijn H:H 1765." (transl.: "a small brown buck as big as a ordinary dog from Iceland drawn at ' $t$ Loo 1756" and: "Guineesche Juffer bokje as big as a small roebuck drawn alive at the menagery of His Highness 1756"). Measurements: $93 \times 145 \mathrm{~mm}$. copied from Vosmaer and Pallas, thus depicting the same specimen.

\section{Procavia capensis}

(Pallas, 1766, Misc. Zool. : 30, Tab. III). (Hyrax).

The drawings are after a live specimen in Zeeland (Pallas in Spic. Zool., Fasc. II, $1767: 20$ ).

In Pallas, Misc. Zool. (1766) Tab. IV, fig. 5-13 signed J. J. Bylaert fec. details of this species are depicted, from a specimen whose rump was given to Pallas by Vosmaer from the Cabinet of the Prince-Stadtholder, who had received the dead animal from "Blauw Jan", a wellknown menagerie in Amsterdam (cf. Engel, $1939: 258$ ) owned at the time by Bergmeijer. This is not the same specimen which is depicted in the Amsterdam edition of Buffon's Histoire Naturelle Suppl. Tome IV (1778) Planche LXV signed: Bergmeijer ad viv del., as is stated explicitly in the text (l.c.: 213).

$a \quad$ An engraving in Pallas, Misc. Zool. (1766) Tab. III, signed: A. Schouman del. S. Fokke sc. In the text the animal is called: Cavia capensis. In the background Sylvicapra is visible (see above II $c$ ).

$b \quad$ An engraving in Pallas, Spic. Zool. (second issue, 1767) Tab. II, signed: A. Schouman delin: C. B. Glassbach sculps.: Berol:.

Reversed copy of $a$, scenery somewhat different, Sylvicapra missing. In the text called: Cavia capensis.

c An engraving in Vosmaer, Regn. Anim. (issue of 1767) signed: S. Fokke fe in the lower part, left, of the engraving. Like $b$, scenery somewhat different. Called in the text: Basterd-Mormeldier.

\section{Cynocephalus spec.}

(flying lemur).

Depicted from a stuffed female specimen in the cabinet of van Heeteren (cf. Vosmaer, Regn. Anim. (issue of 1767):9; Pallas, Misc. Zool. (1766) : 54; Engel (1939) : 280).

$a \quad$ An engraving in Pallas, Misc. Zool. (1766) Tab. VI, signed: A. Schouman del. R. Muijs sc. The animal is called Sciurus petaurista in the text.

b "Sailing Squirrel, N. 349" an engraving in Pennant, A History of Quadrupeds II (edition 1793) Tab. LXXVIII, signed: P. Mazell sculp. Reversed copy of $a$, scenery different.

Depicted from a stuffed male specimen in the Prince's cabinet (also known to Pallas): 
c An engraving in Vosmaer, Regn. Anim. (issue of 1767), C. van Kuik, ad viv. del. S. Fokke, Sc. Striking is the composition with the head of a second animal, so similar to $a$ and $b$. Called in the text: Oostindische groote en langstaartige vliegende Eekhoorn.

$d \quad$ "Le Taguan ou Grand Ecureuil Volant", an engraving in the Paris edition of Buffon's Hist. Nat. Suppl. Tome III (1776) Pl. XXI, signed: de Seve del. Menil Sculp.

Though Buffon states explicitly to have finished his article and figure before he saw Vosmaer's publication, this plate is too much like $c$, be it reversed, not to be included here. Possibly it only demonstrates the restricted possibilities to stuff an animal.

$e \quad$ "Le Taguan ou grand Ecureuil Volant", an engraving in the Amsterdam edition of Buffon, Suppl. Tome IV (1778) Pl. XXI. A reversed copy of $d$, signed: de Sève del. B. de Bakker sculp.

\section{Ateles paniscus}

(Linnaeus, 1758, Syst. Nat. : 26). (Spider monkey)

Lived in "Blauw Jan" and was, after dying and being stuffed, bought by Vosmaer for the Prince's cabinet.

a In the catalogue of the exposition in memory of Schouman (Bol, 1960) 36/cat. 110 at the right side climbing a tree, an animal is easily recognized as similar to $b$.

$b \quad$ An engraving in Vosmaer, Regn. Anim. (issue of 1768), signed: A. Schouman, ad viv. del. S. Fokke, Sc. Called in the text: Amerikaansche BoschDuivel.

It is clear that "ad viv. del." has lost its literal sense: it only means that the artist has seen his object and not merely made a copy of another picture. Even the drawing of a skeleton may be signed "ad vivum delineavit."

\section{Nycticebus coucang bengalensis}

(Lacepède, 1800, Tabl. Mamm. Oiseaux 68 ; cf. Husson \& Holthuis, 1953). (Slow Loris).

This animal lived for some time in the menagerie, but was described only when it was dead and stuffed.

If it was not only described but also painted after its death, the stuffed specimen must have been very lifelike or, at least, it must have been observed alive by Schouman (compare the photographs in "Artis", 10 (1964) : 142).

a An Indian ink painting over a pencil sketch signed: A. Schouman ad. viv. del. (A). According to Bol the picture is authentic, the signature dubious. Measurements: $160 \times 160 \mathrm{~mm}$. (Fig. 3).

$b$ In Bol $(1960,36 /$ cat. 110) at the lower right side Nycticebus coucang is recognizable, exactly like in $a$.

c An engraving in Vosmaer, Regn. Anim. (issue of 1770) signed: A. Schouman ad viv. del. S. Fokke sculp. Reversed copy of $a$. Called in the text: Vijfvingerige Bengaalsche Luiaard.

$d \quad$ "Tailless Maucauco-N. 146", an engraving in Pennant, Hist. Quadr. I (edition 1793) Tab. XLIX signed: P. Mazell Sculp. Reversed copy of $c$, scenery different.

$e \quad$ "Le Loris de Bengale", an engraving in the Paris Buffon edition, Supplément Tome VII (1789) Planche XXXVI, signed De Seve del., veuve Tardieu sc. A copy from $c$, as is stated in the text. Scenery somewhat different.

$f \quad$ "Le Loris de Bengale", an engraving in the Amsterdam edition of Buffon, Hist. Nat. Suppl. Tome VII (1799) facing p. 42 (N.B. in the copy in "ArtisBibliotheek" the paging is at fault, as after p. 48 pagenumbers $41-48$ reappear, whereas the text is continued logically. This, too, is stated on p. 158 of this volume), signed: Hulk Sculp. Reversed copy from $e$.

\section{Cebus spec. \\ (capuchin).}

Died in the menagerie, was stuffed and pictured afterwards.

$a \quad$ An Indian ink painting signed: A. Schouman del. ad: viv. (A.) According to Bol the painting, done up a bit with pen and ink by someone else, is by Schouman, the signature is not. Measurements: $207 \times 162 \mathrm{~mm}$. (Fig. 4).

$b$ In Bol (1960,36/cat. 110), in the lower left, one recognizes $a$.

$c \quad$ In Bol (l.c., 44/cat. 95) between two specimens of Psophia crepitans Linnaeus (Common Trumpeter) a reversed copy of $b$ is visible.

$d \quad$ An engraving in Vosmaer, Regn. Anim. (issue of 1770) signed: A. Schouman, ad. viv. delin. S. Fokke, sc. Reversed copy of $a$. Called in the text: Americaansche Slingeraap. 

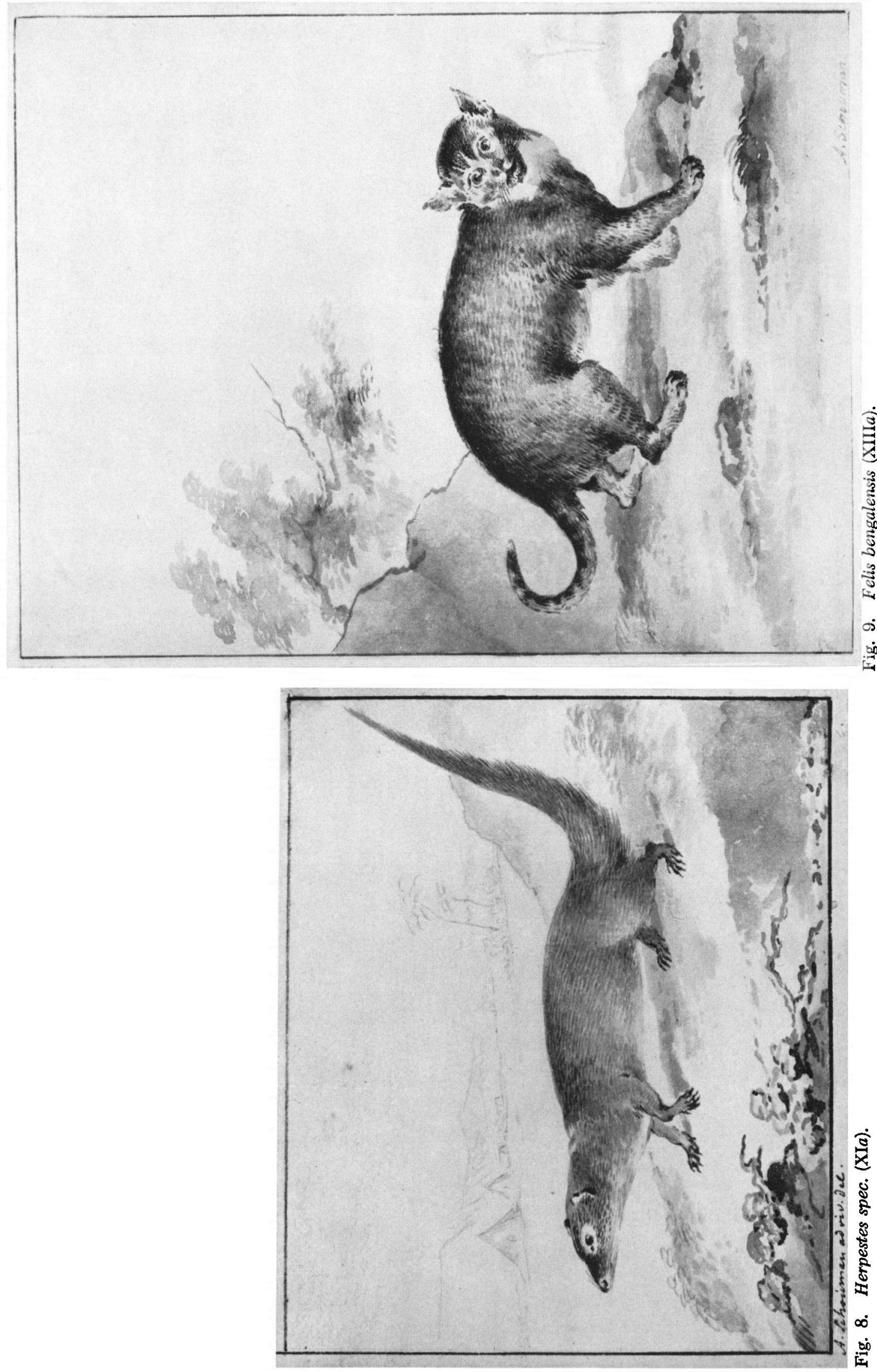

Downloaded from Brill.com04/26/2023 12:13:56PM 


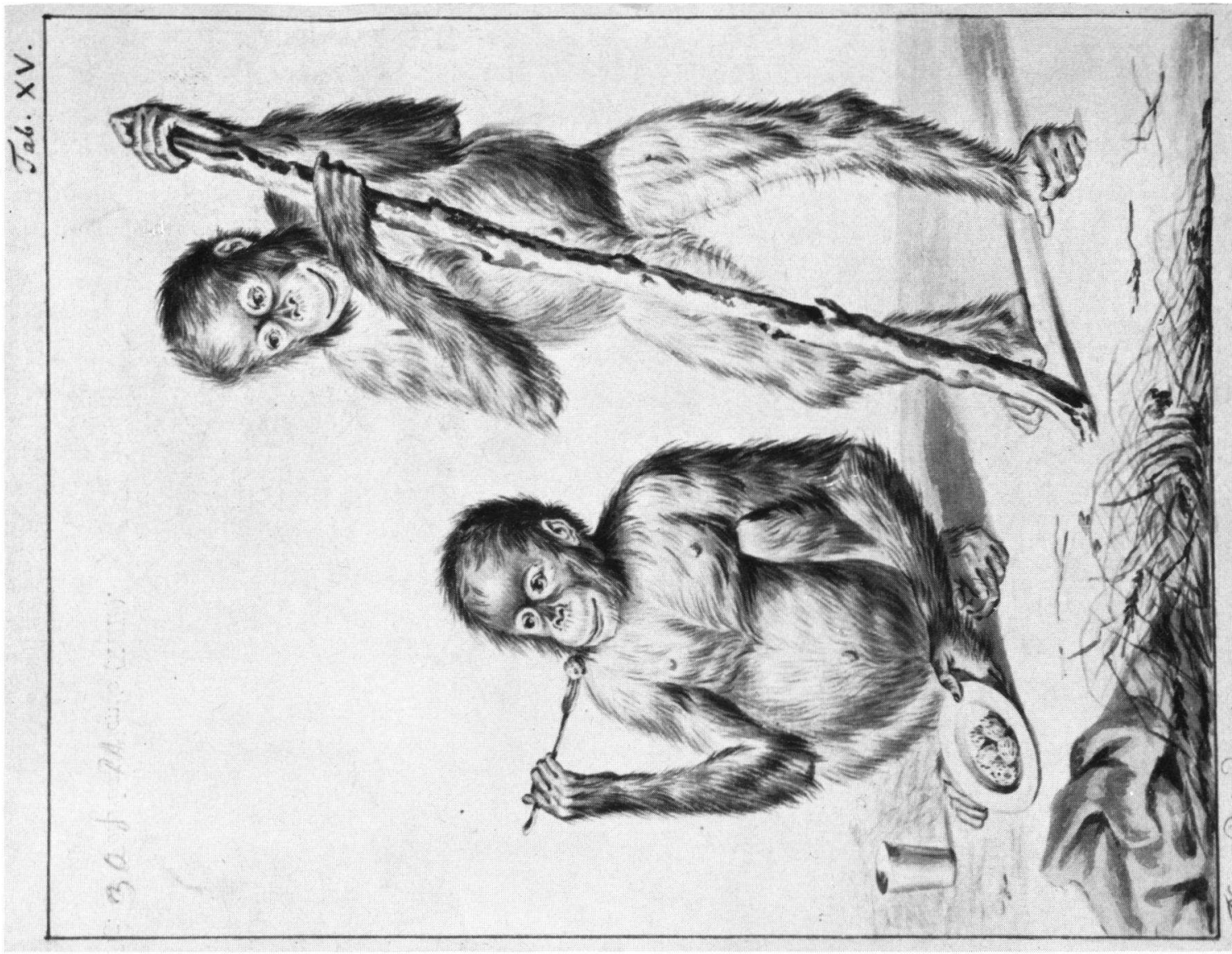

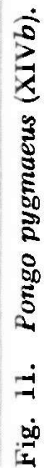

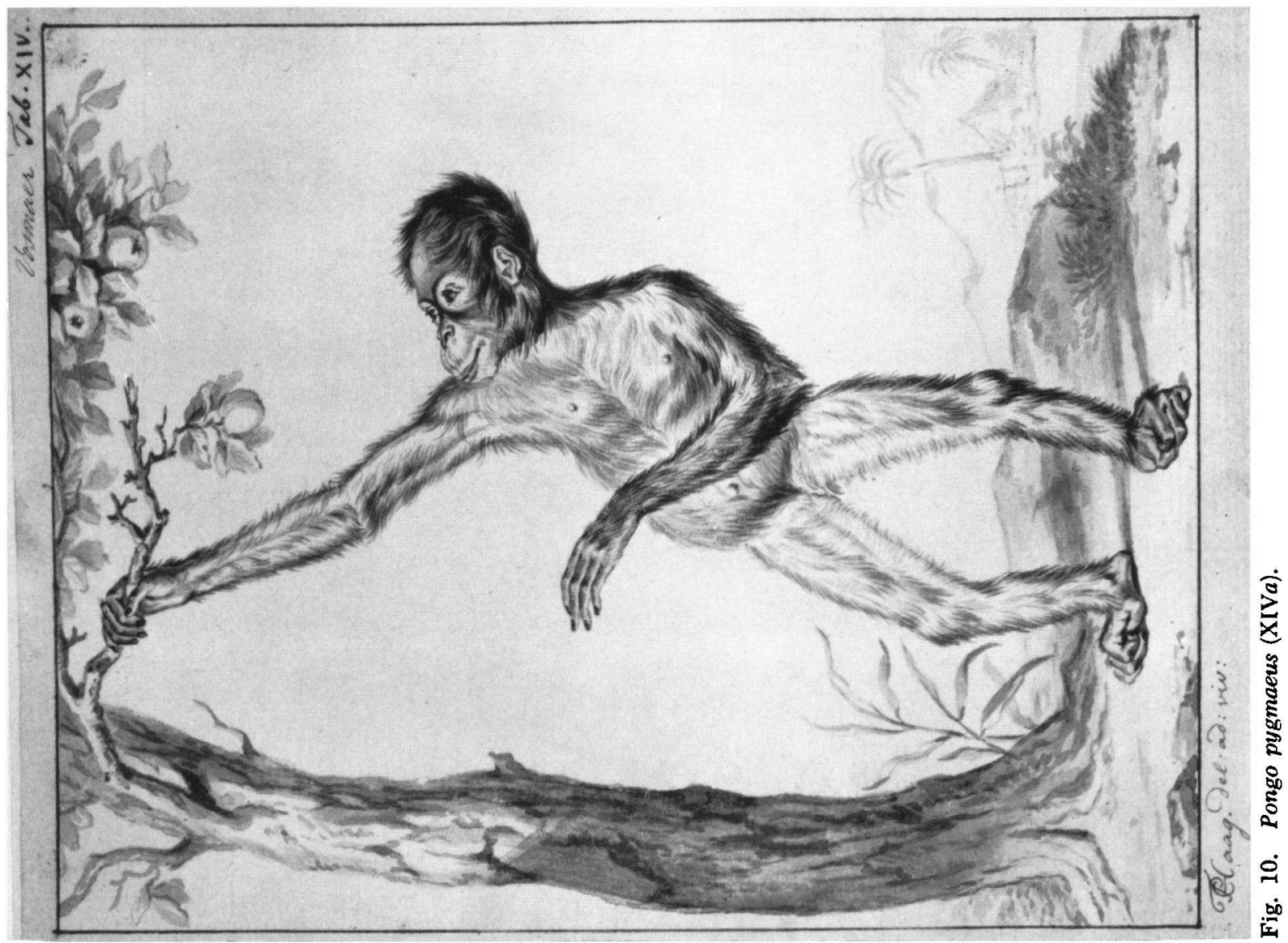


VIII. Genetta tigrina

(Schreber, 1776, Säugth., Tab. CXV). (Large-spotted Genet).

Had been living for 3 years in the Prince's menagerie and was described after it died.

a An Indian ink painting signed: A. Schouman del. ad viv. 1766 (A). According to Bol authentic. Measurements: $204 \times 157 \mathrm{~mm}$. (Fig. 5).

$b \quad$ An engraving in Vosmaer, Regn. Anim. (issue of 1771) signed: A. Schouman, ad viv del. S. Fokke, sc. Reversed copy of $a$. Called in the text: Bizaamkat.

c "Viverra tigrina", an engraving in Schreber, Säugth. (1776) Tab. CXV signed: Schouman del. Tyroff sc. Very much like $b$, scenery different.

$d \quad$ "Le Bizaam", an engraving in the Paris edition of Buffon's Histoire Naturelle Supplément Tome VII (1789) Planche LV, signed De Seve del., De Seve Filius sculp. A reversed copy of $b$, with a different scenery.

$e \quad$ Le Bizaam", an engraving in the Amsterdam Buffon-edition, Suppl. Tome VII (1799) facing p. 92, signed: Hulk sculp. Reversed copy of $d$.

IX. Potos flavus

(Schreber, 1774, Säugth. I : 145). (Kinkajou).

Lived in the Prince's menagerie, was described after it died.

$a \quad$ An Indian ink painting, scenery partly in pencil, signed: A. Schouman, del: ad. viv: (A). Worked up later in ink. Authentic according to Bol. Signature probably not by Schouman. Measurements: $210 \times 160 \mathrm{~mm}$. (Fig. 6).

$b \quad$ An engraving in Vosmaer, Regn. Anim. (issue of 1771) signed: A. Schouman, ad viv. del. S. Fokke, sc. Reversed exact copy of $a$. Called in the text: Amerikaansche Wezel, Potto.

c "Viverra caudivolvula Pall", a coloured engraving in Schreber, Säugth. (1777) Tab. CXXVB, signed: A. Schaumann del. Tyroff Sc. Except the scenery, exactly like $b$.

\section{Bison bison}

(Linnaeus, 1758, Syst. Nat. : 72). (American Bison).

Was shown alive in different towns in 1766 by Lodewijk Singeis from Worms (Vosmaer, $1772: 7$ ). $a \quad$ An Indian ink painting signed: G. V. D. Heuvel, ad vivum. (A). Measurements: $157 \times 157$ mm. (Fig. 7).

$b \quad$ An engraving in Vosmaer, Regn. Anim. (issue of 1772), signed: G. van den Heuvel, ad viv. del. S. Fokke, sc. Reversed copy of $a$. Called in the text: Amerikaansche gebulte stier.

c "Bison jubatus", an engraving in the Amsterdam edition of Buffon, Hist. Nat. XI (1769) facing p. 129, signed: G. van den Heuvel, pinx. 1766 C. F. Fritzsch, sc. Like $b$, scenery different.

$d \quad$ "Le Bison", an engraving in Buffon, l.c., PI. XXV, signed: G. van den Heuvel, pinx. 1766 C. F. Fritzsch, sc. Reversed copy of $c$, scenery different.

$e$ "American Bison-N. 7", an engraving in Pennant, Hist. Quadr. I (edition 1793) Tab. IV, signed: P. Mazell, sculp. Reversed copy of $b$.

Possibly after the same specimen:

$f \quad$ A picture in Bol (1960, 45/cat. 96). As is mentioned in the text, (1.c. : 69, nr. 96) at the back is written: "dit dier na het leven geteekent, had de grootte van een os van 1200 pont. A.S. 1766 in Kannada genoemd wilde ossen. Cabinet Abr. La porte." g "Bos bison Linn.", a coloured engraving in Schreber, Säugth. Tab. CCXVI (1788), signed: A. Schouman, del. J. C. Bock, sc. Reversed copy of $f$. Possibly also after this specimen:

$h \quad$ "Le Bison", an engraving in the Paris Buffon edition, Supplément Tome III (1776) Pl. V. In the text (l.c.: 57) is stated how this animal, caught as a young in northern America, was reward in Holland and afterwards, bought by a Swiss, was transported from town to town in a large cage. That is how Buffon did see it alive.

\section{Herpestes spec.} (mongoose)

Lived in the menagerie, but was described after it died.

a An Indian ink painting signed: A. Schouman ad viv. del. (A). According to Bol: the signature is dubious, but the picture authentic. Measurements: $135 \times 161 \mathrm{~mm}$. (Fig. 8).

$b$ In Bol $(1960,36 /$ cat. 110) in the middle, below, one sees an animal which, apart from the tail, is identical with $a$.

c An engraving in Vosmaer, Regn. Anim. (issue of 1772), signed: A. Schouman, ad viv. del. 
Reversed copy of $a$. Called in the text: Oostindische Krokodillendooder.

$d \quad$ "Viverra Ichneumon $\beta$ Linn.", an engraving in Schreber, Säugth. 3 (1776) Tab. CXVI B, signed: A. Schouman del., I. Nussbiegel sc. Reversed copy of $c$, scenery somewhat different.

\section{Paradoxurus zeylonensis}

(Pallas in Schreber, 1777, Säugth. 3 : 451). (Golden Palm Civet).

Described after a stuffed specimen sent by de Klerk, from Middelburg, to Vosmaer.

Though Vosmaer described A. de Klerk as "sufficiently known by amateurs in Zeeland, Amsterdam and elsewhere, from his Collection of extraordinary beautifully stuffed birds, quadrupeds and other animals", we have not been able to find any exact information about this collection, also mentioned by Schouman in 1767 (Bol, 1960, p. $70 \mathrm{nr}$. 98). A. de Klerk was probably identical with Abrahamus de Clerk, who according to Vogler (1906 : 34) was admitted to the grammarschool at Middelburg in 1729 which school he left in 1735. Abraham de Klerk (or Clercq) was in this town 1763-1772 parish-officer ("diaken") of the Netherlands Reformed Church and 1772-1775 ensign ("vaandrig"), 1776-1780 captain in the civic guard ("schutterij"). He lived in the street called "Langevyle". We do not know his profession.

a An engraving in Vosmaer, Regn. Anim. (Issue of 1773), signed: A. Schouman, ad viv. del. Called in the text: Ceylonsche Bosch-Hond.

$b$ "Ceylonese dog-N. 174", an engraving in Pennant, Hist. Quadr. I (edition 1793) Tab. LII, signed: P. Mazell sculp. Reversed copy of $a$, scenery somewhat different.

XIII. Felis bengalensis

(Kerr, 1792, Animal Kingd. : 151). (Leopard Cat).

Sent to Vosmaer as a stuffed animal by de Klerk, from Middelburg.

a An Indian ink painting signed: A. Schouman (A). Measurements: $196 \times 151 \mathrm{~mm}$. (Fig. 9). In verso is written: "Japansche Bosch Kat van grootte als een ordinaire groote Huiskat by Dhr de Clerk te Middelburg was zeer mak en op 't thuyskomende schip gebooren is noch op straat lopende overreeden". According to Bol, the painting is by Schouman. The text on the back however, is written later by some- one else, though the phrasing is very much like Schouman.

$b \quad$ An engraving in Vosmaer, Regn. Anim. (issue of 1773), Tab. XIII, signed: A. Schouman, ad viv. del. S. Fokke sc. Reversed copy of $a$, markings, especially on the legs, more conspicuous. Called in the text: Japansche Bosch-Kat.

c "Japan Cat-N. 196"., an engraving in Pennant, Hist. Quadr. I (edition 1793) Tab. LIX, signed: P. Mazell Sculp.

Reversed copy of $b$, scenery different, markings more like $a$.

\section{Pongo pygmaeus}

(Hoppius, 1760, Dissertatio academica in qua Anthropomorpha : 7). (Orang Utan).

Usually (for instance in Elliott, $1913: 192$ ) Pongo pygmaeus (Hoppius) is cited with the year 1763. This however refers to a reprint in Amoenitates Academicae of Hoppius' original dissertation.

Lived in the Prince's menagerie, was painted alive $(a, b)$ and described when dead.

a An Indian ink painting signed: T. P. C. Haag. del: ad: viv: (A). Measurements: $205 \times 160$ mm. (Fig. 10).

A similar painting in oils, $174 \times 110 \mathrm{~cm}$, signed T. P. C. Haag pinx. ad viv. 1777 is in the possession of the Mauritshuis at The Hague. A photograph thereof in (A) shows that, save for some minor details and the scenery, the ink and oil-painting are exactly the same.

$b \quad$ An Indian ink painting signed: T. P. C. Haag. del: ad: viv: (A). Measurements: $210 \times 160$ mm. (Fig. 11).

c An engraving in Vosmaer, Regn. Anim. (issue of 1778) Tab. XIV. signed: P. C. Haag del: ad viv. S. Fokke sc. Reversed copy of $a$. Called in the text: Orang-Outang.

$d \quad$ An engraving in Vosmaer, Regn. Anim. (issue of 1778) Tab. XV, signed: P. C. Haag del: ad viv. S. Fokke sc. An almost exactly reversed copy of $b$.

$e$ "Ourang Outang or Great-Ape-N. 86", an engraving in Pennant, Hist. Quadr. I. (edition 1793) Tab. XXXVI, signed: P. Mazell sculp. Exactly reversed copy of $d$.

After the same specimen:

$f \quad$ "L'Orang-Outang", an engraving in the Dutch translation of "L'Histoire Naturelle": Buffon en 

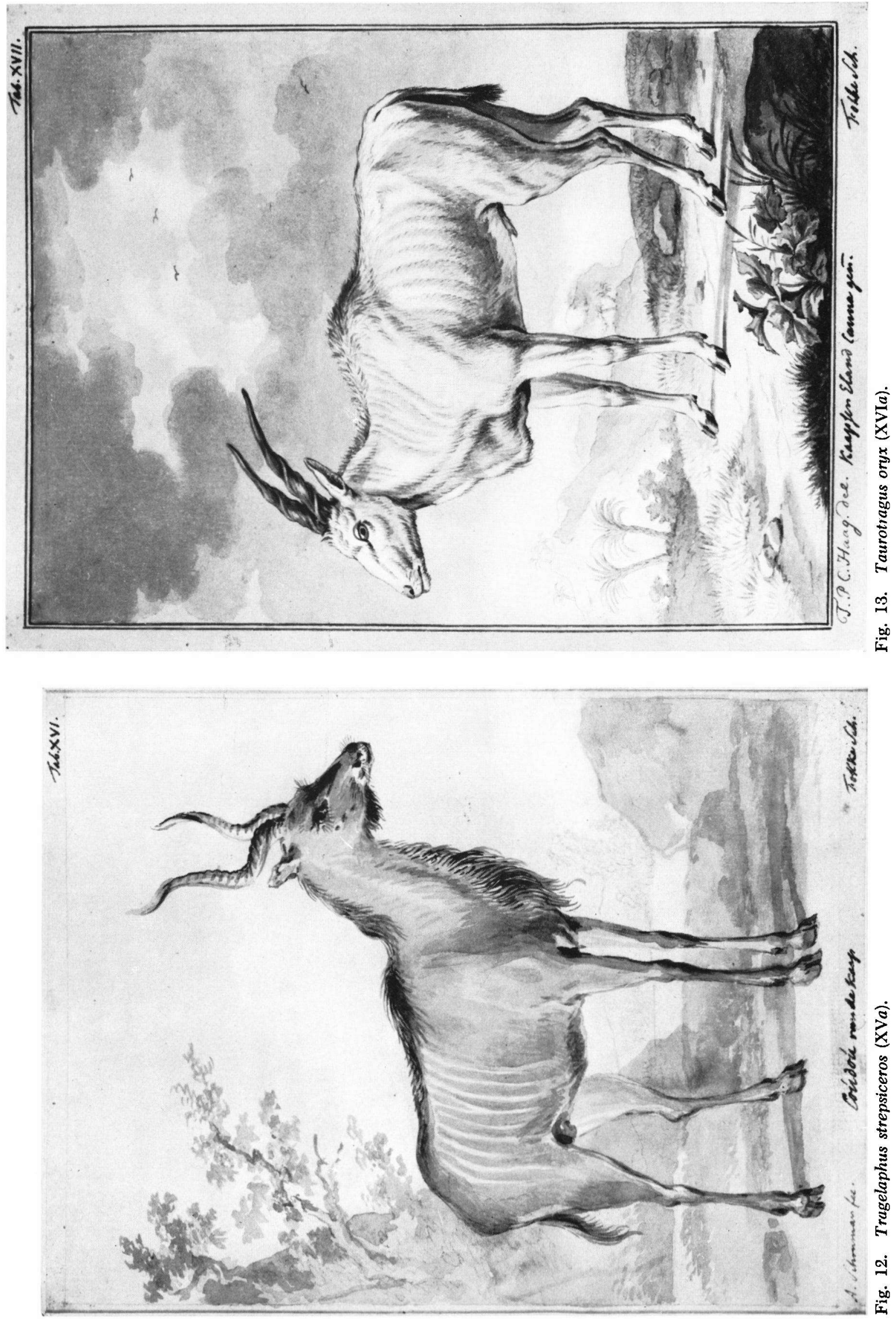


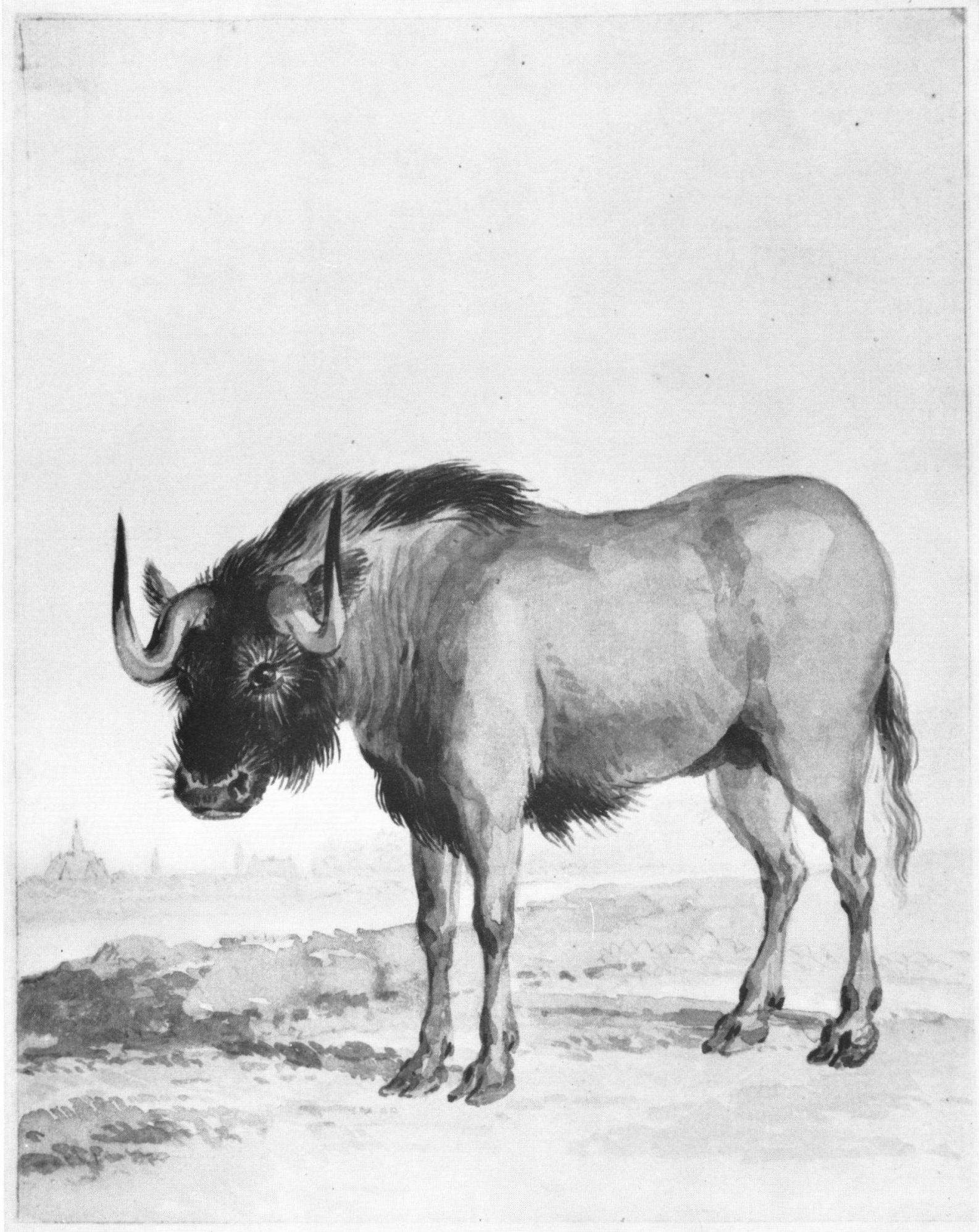

Fig. 14. Connochaetes gnou (XVIIa). 
Daubenton, Natuurl. Hist. XIV (1783) Pl. I, 2, signed: Tringham Sculp. According to the text (l.c. : 49) $c$, $d$ and $f$ all represent one and the same animal.

\section{Tragelaphus strepsiceros}

(Pallas, 1766, Misc. Zool. : 9). (Kudu).

This animal lived in the menagerie of Prince William $\mathrm{V}$ and died after 3 months.

$a$ An Indian ink painting (A). According to Bol by Schouman. Signature not authentic. Measurements: $205 \times 158 \mathrm{~mm}$. (Fig. 12).

$b \quad$ In $\mathrm{Bol}(1960,36 /$ cat. 110), at right, behind a tree, a "coudou" is partly visible, like a reversed version of $a$.

c "Coudou van de Kaap de Goede Hoop", an engraving in Vosmaer, Regn. Anim. (issue of 1783), signed: A. Schouman, del. S. Fokke sculp. Seems a reversed copy of $a$.

$d$ "Striped Antelope-N. 38", an engraving in Pennant, Hist. Quadr. I (edition 1793) Tab. XIV, signed: P. Mazell sculp. Reversed copy of $c$, scenery different.

Different, but after the same animal (cf. Amsterdam edition of Buffon Hist. Nat. Suppl. Tome IV (1778 : 143); Vosmaer, Regn. Anim. (issue of 1784) : 7):

$e$ "Le Coedoes", an engraving in the Amsterdam edition of Buffon l.c., Pl. LXI, signed: I. N. ad vivum del. de Bakker Sc. On the top left of the plate is erroneously engraved :Tome III. The plate number is omitted. In the text is stated how this animal was depicted in Amsterdam, before being sent to the Prince's menagerie.

XVI. Taurotragus oryx.

(Pallas, 1766, Misc..Zool. : 9). (Eland).

Lived ca. 1750 on 't Loo near Apeldoorn in the menagerie of Prince William IV for about 2 years.

$a \quad$ An Indian ink painting signed: T. P. C. Haag. del. (A). Measurements: $207 \times 159 \mathrm{~mm}$. (Fig. 13).

b "Canna of zogeñ: Eland, van de Kaap de Goede Hoop", an engraving in Vosmaer, Regn. Anim. (issue of 1783), signed: T. P. C. Haag, del. S. Fokke sculp. Reversed copy of $a$, sky different.

In 1783 Haag was no longer alive, but he must have drawn the animal in the menagerie about 1750 .

Vosmaer's description is based on another animal, which was sent to the menagerie at The Hague, but died soon after discharge from the ship.

\section{Connochaetes gnou}

(Zimmermann, 1780, Geogr. Gesch., 2 : 102). (Whitetailed Gnu).

Lived for more than 2 years in the menagerie of the Prince. Zimmermann (1777:372-375) quoted the descriptions and measures published by Allamand in an addition to Tome XV (1771) of the Amsterdam Buffon-edition, entitled: "Histoire Naturelle du Gnou, du Grand Gerbo et de l'Hippopotame" published in 1776 and inserted later between the last page (112) of that volume and the first page of the "Concordance et Table alphabétique" which ends the volume, as is evident from the catchword "Concor-"printed at the lower right side of page 112. The inserted pages are numbered 113-126. Though Allamand published an engraving after a painting sent to him from the Cape of Good Hope, he took his measures from the animal in the Prince's menagerie. According to the International Commission for Zoological Nomenclature, Opinion 257 (1948) Zimmermann's work of 1777 is un-available. In his valid publication of 1780 Zimmerman cited, besides Allamand, another article: "Om Djuret t'Gnou Sparrmann. Swensk Wetensk. Handlingar 1779: 76.3 Taf.". We only consulted the German translation of Sparrmann's article (1783), and Zimmermann's valid description from 1780 appeared to be based on the publications of Allamand and Sparrmann both. Therefore the Whitetailed Gnou depicted here (fig. 14) may be considered as a kind of syntype of Connochaetes gnou.

$a \quad$ An Indian ink painting (A). Measurements: $192 \times 152 \mathrm{~mm}$. (Fig. 14). According to Bol possibly by Schouman, who is stated explicitly in Vosmaer's text to have painted this animal (cf $b$ ) in 1774.

$b \quad$ In Bol $(1960,36 /$ cat. 110) at right a Gnou is recognizable, somewhat like $a$ but reversed and more facing depicted. Horns much longer. Behind this animal possibly the female is represented on which Vosmaer (1784:6) commented.

c "Gnou, of zog: Bosch-Buffel, van de Kaap de Goede Hoop", an engraving in Vosmaer, Regn. Anim. (issue of 1784), signed: A. Schouman, del. S. Fokke sculp. A reversed exact copy of $a$.

After the same animal (?):

d A water-colour signed: Vincentius fec. (A). Written in the margin probably by Vosmaer: "met te veel fouten" (transl.: "with too many mistakes"). Measurements: $217 \times 156 \mathrm{~mm}$. 
Wilhelmus Vincentius was a disciple of Schouman. He was baptized at The Hague in 1736, married at Scheveningen in 1765 and is mentioned as a painter in the Registre Civique of 1811 . We are much indebted to Mr. P. A. Scheen, The Hague, for these data which he intends to publish in a new edition of his book "Honderd jaren Nederlandsche Schilder- en Teekenkunst".

Possibly by the same artist as $d$ after a dead specimen:

$e \quad$ A water-colour (A). Measurements: $202 \times$ $152 \mathrm{~mm}$. In verso: "Kleen koebeesje mij onbekend en zeer beschadigd toegezonden zonder te weeten van wien of waarvandaan doch ik denk van Kaap. de G. Hoop. Hoogte 19; Breed 45 duym."

\section{Antidorcas marsupialis}

(Zimmermann, 1780, Geogr. Gesch., 2 : 427) (Springbok).

Lived for 3 years in the Prince's menagerie. Zimmermann (l.c.) refers to Allamand's plate (see below, d) and description in the Amsterdam Buffon edition, supplément Tome IV (1778) : 142-143, and follows Allamand's text closely. Therefore, the animal mentioned here is to be regarded as the type-specimen.

a In Bol (1960, 36/cat. 110), in the middle, at right, this animal is clearly visible.

$b$ "Pronk-bokje, van de Kaap de Goede Hoop", an engraving in Vosmaer, Regn. Anim. (issue of 1784), signed: A. Schouman, del. S. Fokke sculp. Reversed copy from $a$.

c A water-colour signed: Vincentius fec. (A) Written in the margin by Vosmaer: "te slegt om te gebruiken." (transl.: "too bad to use"). Possibly after the same specimen as $a$ and $b$, scenery different. Measurements: $219 \times 157 \mathrm{~mm}$. (Fig. 15).

Different, but after the same specimen (cf. Vosmaer, Regn. Anim. (issue of 1784): 7 Note C):

$d$ "La Gazelle à Bourse sur le dos", an engraving in the Amsterdam edition of Buffon, Hist. Nat. Suppl. Tome IV (1778) Pl. LX, signed: P. L. del. Tringham sculp.

e "La Gazelle ou Chèvre sautante du Cap", an engraving in the Paris edition of Buffon's Histoire Naturelle, Suppl. Tome VI (1782) Pl. XXI, signed: De Seve del., C. Baron sculp. This plate is according to Buffon's text (l.c.: 180) copied from Allamand's Bontebok (Amsterdam Buffon-edition Suppl. Tome V
(1785) Pl. XVI; this is another indication that the volumes appeared in issues (cf Tuijn. 1966, Note III). Buffon (l.c.) states explicitly that Allamand's article on the Bontebok was printed in Amsterdam in 1781. According to the titlepage the volume was completed only in 1784). It is however very hard to imagine that De Sève did not also use as an example the engraving mentioned under $d$. This is the more probable as Buffon suspected both animals to belong to the same species.

\section{Chrysochloris asiatica}

(Linnaeus, 1758, Syst. Nat.: 53). (Cape Golden Mole).

From the Prince's Cabinet.

a A preparatory study in pen and brush (Indian ink) signed: van Noorden Del. (A).

In the same handwriting as the signature?: "Groenglanzige Mol van de Caap de Goed Hoop."

By a different hand: "nog defecten". Measurements: $208 \times 156 \mathrm{~mm}$. The artist is possibly C. van Noorde (1731-1795).

$b \quad$ A water-colour signed: van Noorden Pinx. (A). Measurements: $115 \times 152 \mathrm{~mm}$. Very much like $a$.

c An Indian ink painting signed: van Noorden Del. ad viv. In the same writing: "Groenglanzige Mol van de Kaap de Goede Hoop". In pencil: "deze gevolgd". Measurements: $210 \times 151 \mathrm{~mm}$. (Fig. 16). $d \quad$ "Kaapsche Groen Glanzige $\mathrm{Mol}$ van de Kaap de Goede Hoop", an engraving in Vosmaer, Regn. Anim. (issue of 1787), signed: van Noorden, del. C. Bogerts, sculp. Almost exact copy (N.B. not reversed) of $c$.

$e \quad$ "Cape Mole-N. 441", an engraving in Pennant, Hist. Quadr. II (edition 1793) Tab. LXXXIX, signed: P. Mazell, Sculp. Very much like $c$ and $d$, scenery different.

\section{Giraffa camelopardalis}

(Linnaeus, 1758, Syst. Nat.: 66). (Giraffe).

Described and painted after a specimen in the Prince's cabinet.

$a \quad$ An Indian ink painting signed: G. Haasbroek Del. (A). In the same writing: "Giraf of kameelPaart van de Caap de Goede Hoop". In pencil at the top: "Teek. N 5 of liver de $8^{\mathrm{u}} \&$ goedgekeurd \& gevolgd Tab. XXIa" (?) Measurements: $208 \times 148 \mathrm{~mm}$. (Fig. 17). 


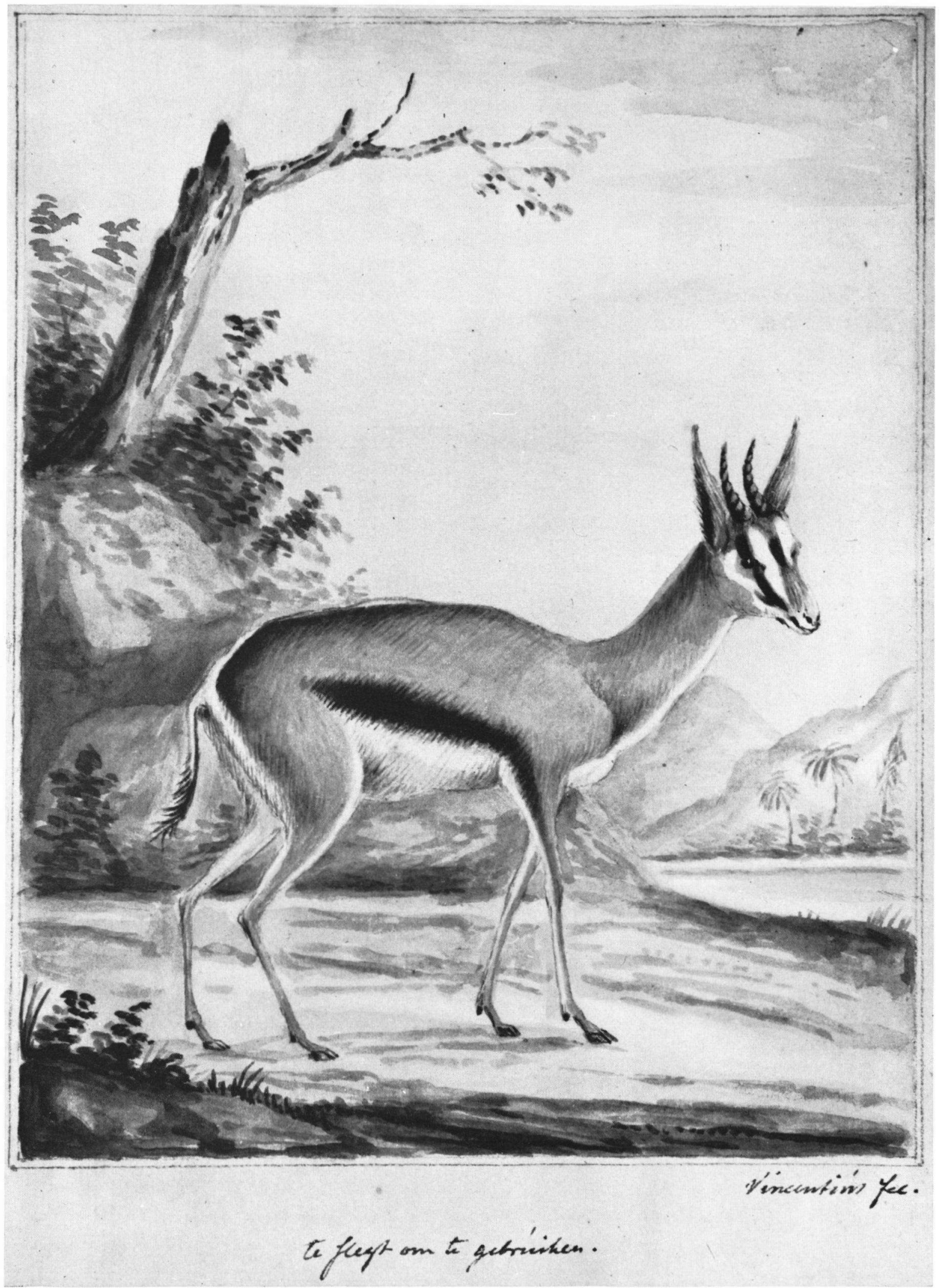

Fig. 15. Antidorcas marsupialis (XVIIIc). 

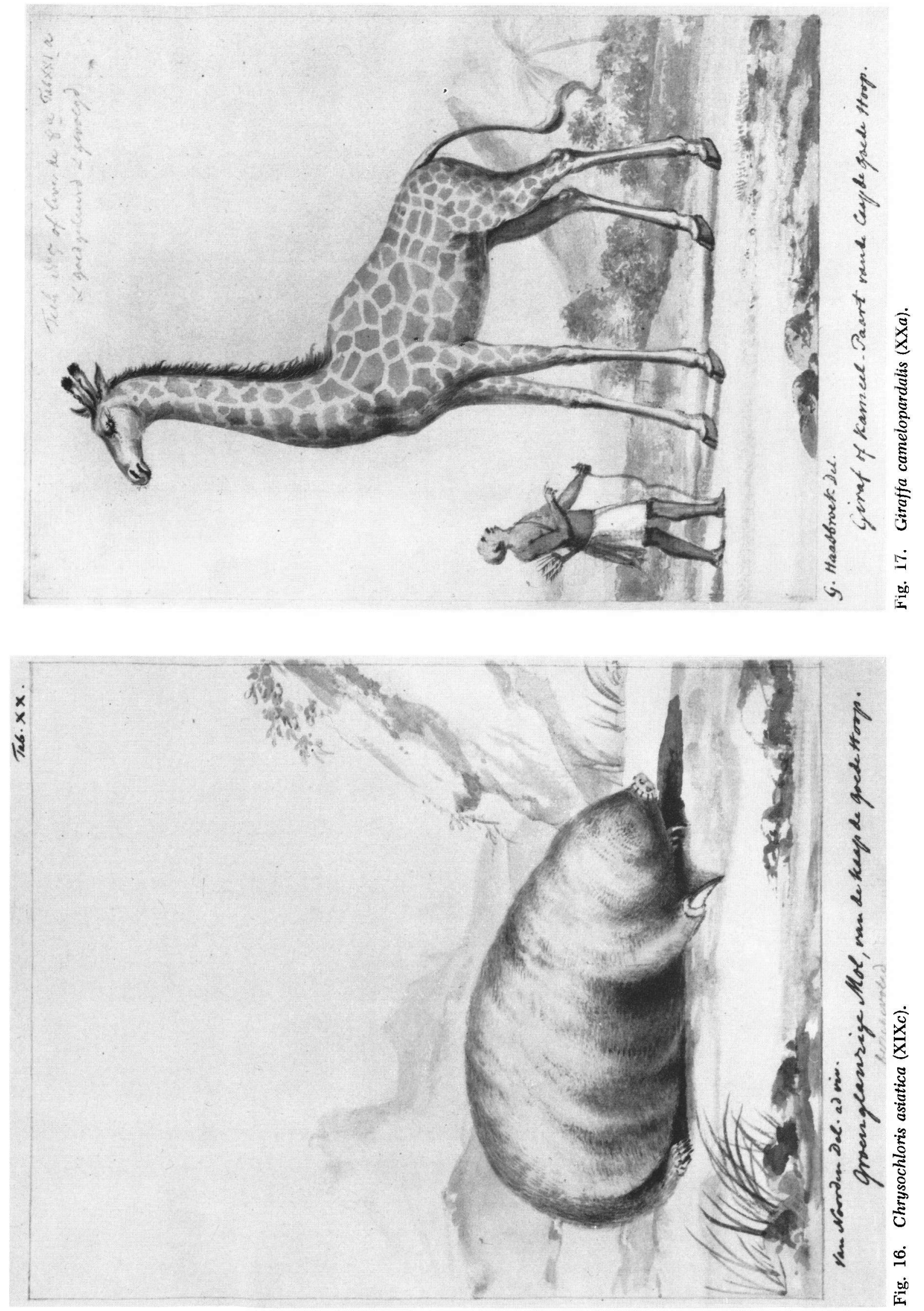
About Geraerd Haasbroek is known that from about 1750-1780 he worked at Rotterdam.

b "Giraffe of Kameel-Paart, van de Kaap de Goede Hoop", an engraving in Vosmaer, Regn. Anim. (issue of 1787), signed: G. Haasbroek, del. C. Bogerts, sculp. Differing in details from $a$. According to the text (Vosmaer, l.c., p. 32) the drawing for this plate was influenced by a sketch by Camper, who gives a description of a giraffe-skeleton in the same issue. This last description is accompanied by an engraving signed: J. F. Gout Sculp 1785. The same engraving may be found as nr. 151 in the volume Quadrupeds of the Gordon-Atlas in the Print Room at the Rijksmuseum in Amsterdam (cf. Tuijn, 1966, Note VI).

\section{Antilope cervicapra}

(Linnaeus, 1758, Syst. Nat.: 69)). (Blackbuck, Indian Antelope).

Not described by Vosmaer, but lived in the Prince's menagerie. (cf. Pallas, Spic. Zool. (1767): 23; Pallas, Dierk. Mengelw. I (1767): 21).

a A watercolour in the collection of Mr. F. Lugt (Anon., 1960: 38, nr. 217), signed A. Schouman. In the centre male and female are clearly visible.

$b \quad$ In the Catalogue of an exposition in memory of Schouman (Bol, 1960) 36/cat. 110 a male and a female like $a$, but reversed.

c In the same Catalogue $37 /$ cat. 97 the female is depicted, like in $a$.

$d \quad$ An engraving in Pallas, Spic. Zool. I (1767) Tab. I, signed: A. Schouman, delin: C. B. Glassbach sc. Berol. Much like the male in $b$. In the text the animal is called Antilope cervicapra.

$e \quad$ An engraving in Pallas, Spic. Zool. I (1767) Tab. II, signed: A. Schouman delin. C. B. Glassbach sculps. Like the female in $b$, reversed copy of $c$, with different scenery.

$f \quad$ An engraving in Pallas, Dierk. Mengelw. I (1767) Tab. A, signed: J. v. Hiltrop fec. Like $d$, scenery different, the whole much more coarsely engraved. In the text the animal is called Hartebok.

g An engraving in Pallas, Dierk. Mengelw. I (1767) Tab. B. signed: J. v. Hiltrop fec. Like $e$, scenery different, the whole coarsely engraved.

$h \quad$ "L'Antilope mâle", an engraving in the Paris edition of Buffon's Histoire Naturelle Supplément, Tome sixième (1782) Pl. XVIII, signed De Seve del: Guttenberg sc. Though Buffon states in the text to have copied this plate from Pallas, it is quite different from $d$ : the animal is standing instead of lying down, the horns, nose, mouth and scenery do not resemble $d$ at all. We do not know another Schouman-drawing by which this plate could have been inspired.

$i$ "L'Antilope femelle", an engraving in Buffon, l.c. Pl. XIX, signed De Seve del. C. Baron sculp. Very much like $e$, though a more slender animal and more finely engraved, scenery different.

$j \quad$ "L'Antilope mâle", an engraving in the Amsterdam Buffon-edition, Supplément Tome Cinquième (1785) Pl. XXVII, signed: De Seve del. O. de Vries Sc. An almost exactly reversed copy of $h$. Allamand clearly preferred Buffon's plate to the original illustration in Pallas's publication.

$k \quad$ "L'Antilope femelle", an engraving in the Amsterdam Buffon edition, l.c., Pl. XXVIII, signed De Seve del. O. de Vries Sc. Almost exactly like i (not reversed!).

\section{ACKNOWLEDGEMENTS:}

We are very much indebted to Drs. P. J. H. van Bree, Zoölogisch Museum, Amsterdam, for help in various ways, whereas the unpublished reports in Artis-Bibliotheek by Mrs M. E. van der Meché-Jacobi (1968) and Mr. H. L. F. du Corbier (1967) have been useful.

The photographs reproduced in this publication (photocopyright Zoölogisch Museum, Amsterdam) were made by Mr. L. R. Hafkamp. 


\section{REFERENCES}

[Anon., 1960:] Bestiaire Hollandais. Exposition de tableaux, aquarelles, dessins et gravures par des artistes hollandais de XVIIe-XVIIIe siècles et d'un choix de livres de la même periode. 1er-27 Mars 1960. Institut Neérlandais, 121 Rue de Lille, Paris VII. Des Presses de l'imprimerie Union Paris: 1-56.

Boddaert, P.: See Paldas, P. S., 1770.

[BoL, L. J., 1960:] Herdenkingstentoonstelling Aart Schouman 1710-1792 (Catalogue of an exhibition in Dordrechts Museum from August 27 till October 23, 1960): 96,64 ill.

Buffon \& Daubenton, [1746 - ] 1749 - 1788: Histoire Naturelle, Générale et Particulière avec La Description du Cabinet du Roy. Imprimerie Royale. 36 vols.

—, 1766 - 1799: Histoire Naturelle, Générale et Particulière avec La Description du Cabinet du Roi. Nouvelle Edition. Amsterdam, J. H. Schneider. Later: Dordrecht, A. Blussé. 38 vols.

- , 1773 - 1807: De Algemeene en Bijzondere Natuurlijke Historie met de beschrijving van des Konings Kabinet. Amsterdam, J. H. Schneider. Later: Dordrecht, A. Blussé. Later: Amsterdam, Johannes Allart. 27 vcls.

Corbier, H. L. F. DU, unpublished: De platen van "Die Säugthiere" van J. Chr. D. von Schreber. Type-script in Artis-Bibliotheek, 1967.

Desmarest, A. G., 1820-1822: Mammalogie ou Description des espèces de mammifères. Paris, chez Mme Veuve Agasse. VIII, 276, VIII, 279.

Elliot, D. G., 1913: A review of the Primates III. American Museum Natural History, New York: I-XVIII, 1, 1-262, I-CLXVIII, 39 pls.

Enger, H., 1939: Alphabetical List of Dutch zoological cabinets and menageries. Bijdr. Dierk., 27: 247-346.

Hoppius, C. E., 1760: Dissertatio Academica in qua Anthropomorpha. Upsaliae (IV): 16.

Husson, A. M., and Holthuss, L. B., 1953: On the early editions of Lacepède's "Tableaux des Mammifères et des Oiseaux", with remarks on two hitherto overlooked species: Lori bengalensis Lacepède, 1800, and Ornithorynchus novae hollandiae Lacepède, 1800. Zool. Med. Leiden, 32 (19): 211-219.

MEChÉ-JacoBi, M. E. VAN DER, unpublished: De Nederlandse tijd van Peter Simon Pallas. Type-script in ArtisBibliotheek, 1968.

Nissen, Claus, 1966 - : Die zoologische Buchillustration. Stuttgart, Anton Hiersemann. Ultimo 1968, 5 issues published.

Pallas, P. S., 1766: Miscellanea Zoologica. Hagae Comitum, Apud Petrum van Cleef. I-XII, 224, XIV Tab.

-, 1767 - 1780: Spicilegia Zoologica. Berolini, prostant apud Gottl. August. Lange. Later: C. F. Voss. Issued in XIV Fasc.; 723, ill.

-, 1770: Dierkundig Mengelwerk, in het welke de nieuwe of nog duistere Zoorten van Dieren door naauwkeurige Afbeeldingen, Beschrijvingen en Verhandelingen opgehelderd worden. In het Latijn beschreeven. Vertaald en met Aanmerkingen voorzien door P. Boddaert. Utrecht,
Abraham van Paddenburg en J. van Schoonhoven. 6 Issues (1767-1770).

Pennant, Thomas, 1771: Synopsis of Quadrupeds. Chester, Monk. I-XXV, 382. 31 ill.

-, 1781: History of Quadrupeds. London, XXIV, 566 (12), 52 ill.

- ,1793: History of Quadrupeds. London. White. 2 Vols. I-XXX, 306, 324, (14), 111 ill.

-, 1793: The Literary Life of the late Thomas Pennant, Esq. By Himself. (I-IV), 144, 1 Portr., 1 Plate.

- , 1948: Tour on the Continent 1765. Ed. with notes by G. R. de Beer. London, Quaritch. I-XII, 178, 9 ill.

Schreber, J. C. D., 1774 - 1846, Die Säugthiere in Abbildungen nach der Natur mit Bescheibungen (fortgesetzt von Aug. Goldfuss und Joh. Andreas Wagner). Erlangen, Wolf. Walther.

Sherborn, C. D., 1891: On the Dates of the Parts, Plates and Text of Schreber's Säugthiere. In: Proc. zool. Soc. London, 587-592.

Sparrmann, A., 1783: Vom Thiere Gnou, einer Art Gazelle oder Antilope, vom vorgebürge der guten Hoffnung. Königl. Schwedischen Akademie Wiss. Abhandl., 41; 65-68, $1 \mathrm{Abb}$.

TuijN, P., 1966: Historical notes on the Quagga (Equus quagga Gmelin., 1788; Mammalia, Perissodactyla) com. prising some remarks on Buffon editions published in Holland. Bijdr. Dierk., 36: 75-79, 3 ill.

VccLER, J. G., 1906: De leerlingen van het Middelburgsch Gymnasium van 1629 tot 1905 . Archief Zeeuwsch Genootschap Wetensch. 1906: 1-82.

Vosmaer, A., 1804: Regnum Animale. Natuurkundige Beschrijving eener uitmuntende verzameling van Zeldsaame Gedierten, bestaande in Oost- en West-indische viervoetige dieren, vogelen en slangen, weleer leevend voorhanden geweest zynde, buiten den Haag, op het Kleine Loo van Z.D.H. den Prins van Oranje Nassau. Amsterdam, J. B. Elwe. Published in 33 issues, 35 ill., Amsterdam, Pieter Meyer (1766-1778). Later: Erven P. Meyer en G. Warnars (1783-1787). Later: J. B. Elwe. (1804).

-, 1804: Regnum Animale. Description d'un recueil exquis d'Animaux Rares, consistant en Quadrupeds, Oiseaux et Serpents, des Indes Orientales et Occidentales. S'ayant trouvés ci devant vivants aux Ménageries appartenantes à son Altesse Monseigneur le Prince d'Orange-Nassau. Amsterdam, J. B. Elwe. Published in 33 issues. Amsterdam Pierre Meyer (1767-1778). Later: Les Héritiers P. Meyer et G. Warnars (1783-1787). Later: J. B. Elwe (1804-1805).

ZimmermanN, E. A. G., 1777: Specimen zoologiae geographicae, quadrupedum domicilia et migrationes sistens. Lugduni Batavorum, Apud Theodorum Haak, et Socios: I-XIV, 1-686, 1 Tab.

- , 1780: Geographische Geschichte des Menschen und der vierfüssige Thiere. Zweiter Band. Leeipzig: in der weygandschen Buchhandlung. I-VIII, 1-432. 
POSTSCRIPT.

When this article was in the press drs. P. J. H. van Bree obtained for the Artis-Bibliotheek a copy of the Vosmaer edition in French. It contains the issues published up to 1778 , ending with the Orang-Utan description. The volume opens with Pierre Meijer's prospectus of Vosmaer's work. This prospectus gives details about the planned scope of the work, the prices of the issues, etc. It is thought worthwhile to publish it here in full:

Avis au public/sur l'édition présentement entreprise d'une / description générale / naturelle et historique, / des plus rares et des plus merveilleuses / productions de la nature, / qui se trouvent \& sont conservées dans le riche dépôt du / cabinet de curiosités, et de la menagerie / de / son altesse sérénissime / monseigneur le prince d'Orange et de Nassau, / stadhouder héréditaire, gouverneur, capi- / taine et amiral général des provinces- / unies des pais-bas, \&c. \&c. \&c. / par / A. Vosmaer, / directeur des cabinets d'histoire naturelle \& de curiosités de S.A.S., membre / de l'academie impériale, \& correspondant de l'academie royale des / sciences de Paris. / Cet ouvrage, comme son titre l'annonce, ne sera composé que des découvertes les plus récentes qui auront été faites, touchant des quadrupedes, oiseaux poissons, serpens, insectes \& autres reptiles, crustacés \& testacés, crystaux \& fossiles, pétrifications, minéraux / \& pierres, dont la forme permet une bonne figure : toutes choses nouvelles, desquelles on a déja bon nombre, \& cependant l'on ne publiera rien que ce qui n'a encore jamais été connu, gravé \& coloré, ou bien représenté $\&$ bien décrit.

Quoique le titre général semble insinuër que cette collection ne renfermera qui ce qui se trouve dans le cabinet $\&$ dans la ménagerie du Prince, nous ne nous y bornerons cependant pas jusqu'à refuser de faire usage, sur les traces d'autrui, de quelque article inconnu, qui se présentera ailleurs : au contraire, nous donnerons toujours une place convenable, dans notre ouvrage, à de tels morceaux, lorsque leurs possesseurs nous en accorderont la description \& la figure, sous la mention de leurs noms. Nous croyons, par ce moyen, pouvoir accelérer d'autant mieux notre grand objet, qui est d'enrichir les connoissances des Etres de la Nature.
Néanmoins ce cabinet \& cette ménagerie, que l'abonclance \& la variété de leurs sujets rares \& précieux ont rendu si celèbres, formeront la principale source de notre entreprise; source, nourrie encore journellement par un concours de matériaux de toutes les quatre parties du monde ; desorte qu'on comprendra aisément, qu'il ne nous manquera point de sujets dignes d'être connus; et bien qu'un ouvrage de ce genre ne puisse jamais être porté à la perfection, vû la continuïté perpétuelle des nouvelles découvertes dans le règne inépuisable de la Nature, l'on ne sauroit pourtant non plus jamais le tenir pour imparfait : chaque partie est en elle-même complette ; \& les amateurs n'ont point à craindre ici le desagrément qui arrive d'ailleurs souvent dans de semblables ouvrages, quoique formés sur un autre plan.

A l'égard du format, nous avons choisi le grand 4to. pour égaler en cela les ouvrages de Mrs. Buffon \& Edwards ; \& quant aux figures, nous les faisons exécuter, sous nos yeux, avec tout le soin \& tout l'art possible, pour qu'il n'y manque rien du côte de l'exactitude.

Nous avons réglé l'edition, par deux planches à la fois, accompagnées de leurs descriptions particulieres, \& nous continuerons sur ce pied avec toute la diligence dont nous serons capables. Ne pouvant nous assujettir à aucun ordre dans le cours de la publication, les amateurs seront par ce moyen mis en état de rassembler à part les quadrupedes, les oiseaux, les poissons, \& $c$. Pour cet effet, l'on distinguera les planches \& les pages d'impression de chaque classe, par des lettres numerales conséquentes ; \& chaque nombre convenable de planches \& de descriptions sera de plus pourvû d'un titre général, \&c. Le prix de chaque planche avec sa description en hollandois ou en françois, quelque étenduë que celle-ci puisse être, a été fixé à 10 sols, \& colorée à 16 doutons-nous pas d'être encouragés par le bon succès, dans un tems dont on peut dire que l'histoire naturelle est devenuë l'etude universelle \& favorite.

L'Ouvrage se publice à Amsterdam, chez Pierre Meijer, Libraire sur le Vygendam, \& chez les principaux libraires dans les autres villes des provinces-unies, \&c. où l'on peut avoir cet Avis gratis. 